\title{
Centennial History of the APS
}

\author{
HOWARD A. PEARSON
}

Department of Pediatrics, Yale University School of Medicine, New Haven, Connecticut 06510

The American Pediatric Society was founded during the last part of the 19th century, at a time when scientific medicine was just emerging from the shadows of empiricism and polytherapy. Pasteur and Koch had laid the foundations of bacteriology only a decade before. Diagnostic techniques such as the roentgen ray had not been discovered. Chemical analyses were limited and not applicable to infants and children.

These were perilous times for children. Infant mortality was in excess of 200 per 1000 births. Summer diarrhea, a plague that was largely a consequence of bad food, bad sanitation, and bad milk killed thousands of babies annually. Devastating epidemics of diphtheria, scarlet fever, polio, and other infectious diseases occurred with regularity. The feeding of infants was empiric and deficiency diseases such as scurvy and rickets were prevalent.

Academic pediatrics in the 1880 s was an underrecognized, underserved academic area. There were only about half a dozen children's hospitals in all of the United States. When taught at all in American medical schools, pediatrics was an abbreviated section under obstetrics or internal medicine. Throughout the country, there were only about fifty physicians who could be identified as being interested and involved in the medical problems of infants and children. National pediatric organizations were virtually nonexistent, but the health problems of children were so monumental that the time was ripe for action.

The major impetus for the organization of the American Pediatric Society came from Job Lewis Smith of New York who saw clearly the need for a forum for the discussion of pediatric issues and clinical problems. Justifiably, he has been called the father of the American Pediatric Society.

Smith was born of Yankee stock in the Finger Lakes district of upper New York State. After attending Yale, he studied medicine in Buffalo under the great physician Austin Flint and later graduated from the College of Physicians and Surgeons in New York. Smith was one of the first American physicians to devote much of his practice to the care of children, and he became a local and a national leader in this area.

In September 1887, after a meeting of the pediatric section of the Ninth International Medical Congress in Washington, D.C., of which Smith was the chairman, he invited half a dozen physicians to meet with him for the express purpose of setting into motion the establishment of the American Pediatric Society. At this preliminary meeting, Smith was appointed temporary president of the fledgling American Pediatric Society, and William Booker of Baltimore was appointed secretary pro tem.

Over the next year, Smith and Booker circularized American and Canadian physicians whom they knew to be interested in the problems of children. Most of those whom they contacted were supportive and expressed an interest in joining the new society.

A year later, on September 18, 1888, a formal organizational meeting was held in Washington, D.C. Fourteen physicians met in the Arlington Hotel that September morning. It is the 100th anniversary of that organizational meeting that we celebrate today.

The first order of business was to appoint a committee, consisting of Abraham Jacobi, Booker, and William Watson, to draft a constitution. The committee completed its task rapidly. In less than two hours, a complete constitution with 14 articles was presented and then accepted.

Over the years, a number of writers have marvelled at the celerity with which the committee completed its task. The ease and rapidity were undoubtedly due to the fact that the newly drafted American Pediatric Society constitution was a nearly verbatim copy of the constitution of the Association of American Physicians that had been founded only two years before. The two societies' constitutions were printed in volume I of their respective Transactions. Except for the difference in the names of the societies and a few minor words, the constitutions were identical. Jacobi had also been a founding member of the Association of American Physicians, and was familiar with its constitution. Ever the pragmatist, the father of American pediatrics apparently felt no need to reinvent the wheel.

The next order of business was the election of the first officers and council. Abraham Jacobi was our first president. Frederick Forcheimer and Arthur Meigns were the first vice-presidents, and William Booker was the secretary.

The 43 founding members were then elected. They came predominantly from the Northeast, especially New York, but some were from as far as Chicago and Canada. Most had affiliations with medical schools. In a tonsorial analysis of our 43 founding members, Faber and Macintosh in their 1966 history reported that $44 \%$ of the founders wore beards, $56 \%$ had mustaches, and only $9 \%$ were clean shaven.

Over our first hundred years, the primary raison d'etre for the Society has been to present an annual scientific meeting. Although there has been a broad array of content and location, the meetings have, with only two exceptions, been a rite of spring, usually in May. The locations have spanned the continent, but generally favored the East Coast. During the first 50 years, when the total membership was less than 100 , the Society showed a preference for small bucolic sites. A compelling reason for these choices was their proximity to good golf courses, of which more will be said a little later.

Several of the scientific meetings were truly memorable and are worth brief descriptions. Our first scientific meeting was held in Washington, D.C. in September 1889 in the library of the U.S. Surgeon General, Dr. John Billings. The second session was held that same evening in a parlor in the Arlington Hotel, probably because the Surgeon General's library was closed at night. The next morning the Society members boarded the train in Washington for a 1-hour trip to Baltimore where they finished their meeting in the new Johns Hopkins Hospital which had been opened only four months before. At this meeting, Jacobi presented the Society's first presidential address entitled, "The Relationship of Pediatrics to General Medicine." Twenty-seven papers were presented. The discussions, as was characteristic of the early Society, were extensive and spirited.

The 39th meeting of the Society was inarguably the most memorable before or since. The Society met on board a Chesapeake Bay cruise ship, the SS Southland, for three days of what has been called "riotous revelry" interspersed with scientific discussions. It is clear from reading the record that this meeting was liquid in more than its maritime location. Informality prevailed; only first or "pet" names were allowed to be used. On the 
second night an elaborate skit entitled The Pirates of Pediatrics, a parody of HMS Pinafore, was presented. This was followed by a fancy dress ball complete with improvised costumes such as shower curtains and ladies' dresses. Despite the warm ambience of this meeting, the society never again engaged in such frivolity-alas.

The meeting in May 1960 was held in Swampscott, Massachusetts at the New Ocean House, an aging dowager of a hotel about 30 miles north of Boston. In many ways, the meeting was a near disaster. There were not enough rooms and massive overbookings were made. Members were forced to share their rooms, sometimes with strangers. One legend had Dr. Helen Taussig being assigned to the same room as two junior male residents. Bill Cleveland tells a story in which, at 6 a.m. one morning, Bill Nelson was awakened by a call from a frantic hotel operator demanding, "Is Dorothy Anderson in this room?" Without a second of hesitation, Nelson is said to have replied, "That, Madam, is a question no gentlemen would answer." The scientific sessions were held in a grease stained, vacated garage. Lights and loud speakers did not work, but somehow the meeting was completed. Even 25 years later, as Henry Barnett has said, "Stories of Swampscott, like Abou Ben Adhem, lead all the rest."

The 75th anniversary of the Society was a watershed. It was held in Atlantic City in May 1963. Attendance of the annual meeting had grown so large that plenary sessions could not be accommodated in most of the hotel ballrooms of the time. Therefore, the Society leased an auditorium on the Steel Pier. Within the vast cavern of the Steel Pier Theatre, the last vestiges of a small society with intimate meetings ended forever.

For the next 10 years, the Society met in Atlantic City, The boardwalk served as a place for informal meetings and discussions. It was rumored the prostitute corps of Atlantic City scheduled their vacations during the weeks of the Society meetings because business was so slow at that time. Then, in the early 1970s, casino gambling was legalized and Atlantic City and its hotels became incompatible with the spring meetings.

The first 50 years of our Society have included many great men and women who advanced the cause of pediatrics immeasurably. It is fitting perhaps to briefly note a few of our greatest early leaders.

Abraham Jacobi, twice president of the APS, dominated American pediatrics for nearly half a century with his political astuteness, enthusiasm, and effectiveness. L. Emmett Holt, Sr., was the only other two-time president of the APS. Holt wrote a landmark pediatric textbook and introduced scientific inquiry and laboratory investigation into American pediatrics. John Howland, Holt's protege, built the first fulltime pediatric department at Johns Hopkins and the Harriet Lane Home. Howland and his associates dominated American pediatrics for a quarter of a century.

In 1951, the Society inaugurated a formal process to recognize its most luminary members by establishing the John Howland Award. The award was authorized under Article 2 of the constitution, which stated that an objective of the Society was to honor those who, by their contributions to pediatrics, have aided in its advancement. A handsome medal was struck that showed John Howland's profile on the face and the inscription "For distinguished service to pediatrics" on the obverse. The Howland Medal has been awarded 27 times, including the Centennial Celebration Award to Dr. Dancis. The recipients of the award represent a pantheon of American pediatrics. These individuals have collectively brought more honor to pediatrics than the Society can ever return.

Great attention was given to golf during the first 75 years of the Society. From today's scientific and businesslike perspective this may seem a little quaint and even frivolous. However, in the context of the Society's small size and fraternal ambience, golf facilitated communication and was deeply loved by many. The society's involvement in golf was said to have started in 1914 when Emmett Holt led John Howland astray from an afternoon scientific session in order to play golf. The departure of these great leaders was duly noted and emulated by many others in subsequent years. By 1922, the derelictions became so frequent that the council decreed an afternoon during the meeting free for sport.

In 1923, a formal golf tournament was inaugurated. Philip van Ingen donated a silver cup for the winner of the tournament. This was engraved with the words, "The American Pediatric Society President's Cup" on one side. Through 1972, the names of the winners were inscribed on the reverse. The great golfers of the American Pediatric Society were John Howland, James Gamble, and James Baty, who all consistently shot in the low 80 s.

The membership of the American Pediatric Society has changed quantitatively if not qualitatively over the past 100 years. For its first 50 years, the Society was small and elite. The constitution initially set a limit of 60 members and then successively increased it to 75 in 1912; to 90 in 1927; and to 100 in 1930. Finally, in 1938 a constitutional amendment was passed that removed any limitation to the number of active members. Membership over our first 100 years showed an increasingly rapid rate of Society growth over the last 35 years (Fig. 1) that has been attributed to the removal of membership limitations in 1938 and to the post-World War II expansion of pediatric departments. However, rapid growth has not been exclusively a recent phenomenon. When the logarithm of the number of Society members is plotted against time, the rate of growth of Society membership has been exponential since 1910 (Fig. 2). The rate of growth shows no indication of leveling off and it is likely that active membership will be in excess of 1500 by the turn of the century, compared with 923 active members today.

The first woman elected to Society membership was Ethel Dunham, of New Haven and Washington, D.C., who was admitted in 1928. Since then, the total number of women members has increased greatly, but over the past 40 years has remained steady at about 9 to $10 \%$ of the total membership. The first black member of the Society was Dr. Roland Scott of Washington, D.C., who was admitted in 1952 .

Over its first 100 years, the Society has had a total of 1523 members. Seventy-five percent of the total 100-year membership is alive and hopefully kicking at the time of our centennial celebration.

Over the past 100 years the Society has followed an evolutionary course, driven and selected by changes in American medicine and science as well as by social and governmental pressures. Our society's 100-year history can be conveniently, if arbitrarily, divided into seven successive eras (Table 1).

The first era, 1888 to 1900 , can be designated "Darkness and

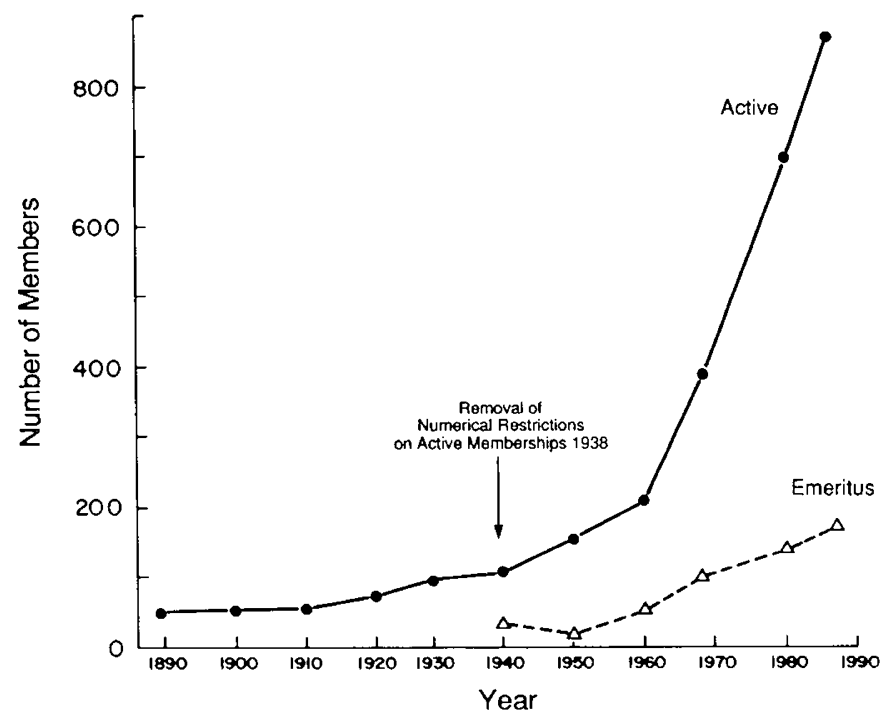

Fig. 1. Membership-American Pediatric Society, 1889-1987. 


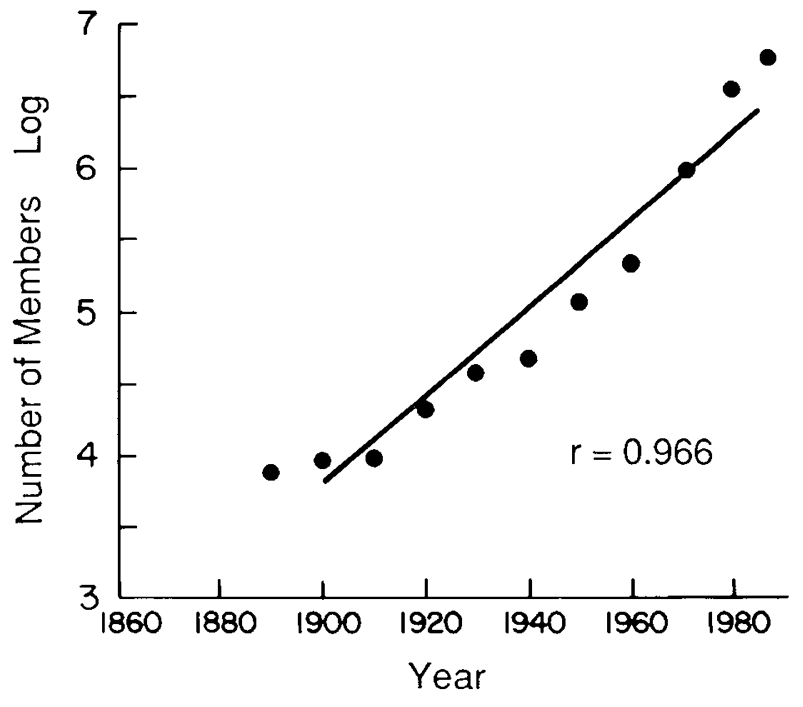

Fig. 2. Logarithm of membership-American Pediatric Society, 1889-1987.

Table 1. Eras of American Pediatric Society

$\begin{array}{ll}1888-1900 & \text { Darkness and dawn } \\ 1901-1915 & \text { New century: new developments } \\ 1916-1938 & \text { Pediatric biochemistry flowers } \\ 1939-1945 & \begin{array}{l}\text { Wartime slowdown } \\ \text { The postwar boom-fueled by } \\ \text { Federal funds }\end{array} \\ \begin{array}{l}\text { 1966-1965 } \\ \text { Specialization and fragmentation } \\ 1981-\end{array} & \begin{array}{l}\text { Plateau and "the New Biology" } \\ \end{array}\end{array}$

Dawn." The Society's first decade was characterized not only by follies such as Thomas Morgan Rotch's "percentage system" for infant feeding; but also by a few triumphs, especially the discovery and widespread deployment of diphtheria antitoxin, with spectacular reductions in mortality. Preoccupation with safe milk was evident and appropriate, given the devastating consequences of an unsanitary milk supply. Laboratory investigation was almost nonexistent. The Society's major role was to provide a forum for discussion and exchange of ideas and experiences. Presentations at the Society's annual meetings were almost exclusively reports of one or a few interesting cases.

The next era, "New Century, New Developments," was between 1901 and 1915. During this time, pediatricians and the Society became increasingly aware of major public health and welfare issues that affected children. Social resolutions were passed to address these, but few actions were taken. The Society was truly divided concerning its appropriate role in social issues, and this schizophrenia continues to this day. Great attention was given to descriptions and discussions of epidemic diseasessummer diarrhea, meningococcic meningitis, polio, typhoid, and others. These studies were sharpened by advances in microbiology. Infant feeding was still discussed at great length but became progressively simplified. Pioneering biochemical investigations began with Holt and his initiatives were continued by his protege, John Howland.

Research in nutrition and biochemistry flowered during the era from 1916 to about 1938, led by the laboratories of Howland, Hess, and Schloss, and later, led by Gamble, Darrow, Butler and others. Quantitative measurements were increasingly applied to pediatric problems. These topics formed the basis of many of the reports at the annual meetings.

At a meeting in the late $20 \mathrm{~s}$, one member, on mounting the platform, twittingly apologized for "presenting a clinical case to this society of biochemists." However, high quality clinical descriptions and investigations continued to be presented and discussed at the annual meetings. The Society was fraternal and small, less than 100 members, and nonmedical activities were an important part of the annual meeting.

Next, there was a wartime slowdown between 1939 and 1945. The total involvement of America in World War II had a major impact on the Society. Annual meetings were cancelled in 1943 and 1945. Many pediatricians were called into military service and those left behind had to shoulder large teaching and clinical loads that precluded much involvement in research or in the Society.

With the end of the war, from 1946 to 1965 , the postwar boom era fueled by federal funds occurred.

Released from wartime restraints and replenished by physicians returning from the service, a marked expansion of pediatric departmental personnel and research was seen. This was, in large measure, an era encouraged and supported by the Federal government, especially the National Institutes of Health.

Research technology became more sophisticated and subspecialization began to dominate many academic departments. These trends were reflected in the Society's program by an increasing emphasis on technical research papers in ever smaller areas. Following the example of the Society for Pediatric Research, a portion of the annual meeting was devoted to simultaneous subspecialty sessions rather than plenary sessions.

The era between 1966 and 1980 can be designated "Subspecialization and Fragmentation." Subspeciality-based research became increasingly the academic norm. Communication became more difficult not only between general and academic pediatricians, but also among subspecialists. Subspecialty organizations sprang up, many of which held their own research and clinical meetings. Papers that in previous years would have been submitted to the American Pediatric Society were presented elsewhere. Greater subspecialty orientation at meetings was evident, and more and more of the program was devoted to simultaneous subspecialty sessions.

Throughout this period, the American Board of Pediatrics, the American Academy of Pediatrics, and the American Society of Pediatric Department Chairman became increasingly involved in the overview of teaching and training. Members of the American Pediatric Society served in leadership roles in other pediatric societies and organizations. This professional incestuousness diminished the uniqueness of the American Pediatric Society. Its greatly increased size may have also decreased the elite cachet of Society membership.

The last era, 1981 to the present, might be designated "Plateau and the New Biology." By the mid-1970s, federal expenditures for research had plateaued. Rather than a lack of physicians, a glut was predicted. Clinical practice increasingly became an important source of departmental support, sometimes impinging on faculty research time. A true revolution in medicine, the socalled "New Biology" began to have an increasing impact. Dazzling new technologies such as recombinant DNA, magnetic resonance, and cell biology became the glamour areas of research. Complex and technically sophisticated methodology was developed to probe biologic mechanisms at cellular, subcellular, and molecular levels. State of the art lectures and special symposia were organized to explain some of these complicated areas to the membership. Plenary sessions of the Society became joint sessions with speakers chosen jointly with the Society for Pediatric Research. Perhaps more than at any other time in our 100-year history, a dichotomy has become apparent between basic and clinical investigation and investigators.

The changes in the American Pediatric Society and its meetings over its first 100 years clearly reflect changes in pediatrics itself. In recent years, the American Pediatric Society has become essentially only one component of a conjoint pediatric society that includes not only the American Pediatric Society and the Society for Pediatric Research, but also, because of multiple and overlapping membership, the American Society of Pediatric Department Chairmen, the American Board of Pediatrics, the American Academy of Pediatrics, and many others. 
These changes have occurred primarily as an evolutionary process rather than by deliberate decisions by the Society. Our challenge at this centenary is to decide whether this new role is what the Society wishes or whether changes of emphasis and direction are in order if a degree of individuality, independence, and unique mission of the Society is desired. As we enter our second 100 years, we should ask, "How can the American Pediatric Society effectively meet its constitutional objectives to bring together men and women for the study of children and their diseases; for the prevention of illness in childhood; for the promotion of pediatric education and research; and to honor those who, by their contributions to pediatrics, have aided in its advancement?"

A nostalgic comment made at the Society's 1938 semicentenary by Thomas Cooley may be as good a way as any to end this presentation: "I have always been convinced that no other of the special societies has so fine a group as ours. This is due, I think, to the fact that Pediatrics is definitely the most idealistic of the specialties and for that reason has brought together a particularly unselfish and lovable company."

To which I can only add, "amen." 